\title{
Performance of Wheat Crop (WH-1105) Yield between Front Line Demonstrations and Farmers Practices
}

\author{
Fateh Singh, M. K. Singh*, Praduman Bhatnagar and Mamta \\ KrishiVigyan Kendra, Kurukshetra, Chaudhary Charan Singh Haryana Agricultural \\ University, Hisar, India \\ *Corresponding author
}

A B S T R A C T

Keywords

Front Line

Demonstration, Farmers Practices,

Wheat yield,

Benefit Cost ratio

Article Info

Accepted:

12 January 2021

Available Online:

10 February 2021
Krishi Vigyan Kendra, Kurukshetra, Haryana has conducted Front Line Demonstrations (FLD) in different villages of Kurukshetra to find out the yield gap between improved package practices applied in FLD with traditional farmers practices (FP) on wheat crop (WH-1105) under irrigated condition. It was observed that, the yield of wheat in FLD were ranges from 54.6 to $56.8 \mathrm{q} /$ ha whereas, in FP it were found 51.2 to $53.6 \mathrm{q} /$ ha during 2017 18 to 2018-19. The percent yield of wheat crop was more in FLD than FP. The Extension gap of wheat crop between FLD and FP was found 3.4 and 3.2 q/ha, technological gap was ranged 8.8 and 6.4 and technological index was 9.0 and 12.6 during 2017-18 and 2018-19 respectively. The average cost benefit ratio was 2:42 and 2:10 in FLD and FP respectively. The yield gap of wheat crop between FLD and FP may be due to the farmers has not followed the instructions as mentioned in Package and Practices of Rabi crop develop by CCSHAU, Hisar from sowing to final harvest period.

\section{Introduction}

Wheat (Triticum aestivum L.) is the second important cereal crop in India after rice by providing more than 50 percent calories to the people. In India, Uttar Pradesh, Haryana, Punjab, Madhaya Pradesh are the highest wheat producing states. Wheat is a source of protein, glucose, fat and mineral matter and good source of nutrition reported by Munns and Tester., (2008) and Shiferaw et. al., (2013). Production of wheat crop depends upon the duration of cold period, sowing time, timely application of fertilizers, irrigation, pesticides etc. Total contribution of wheat in food security is 36 percent of whole food grains produced in India. The productivity of wheat per unit area could be increased by adopting scientific and sustainable management practices reported by Ranawat et. al., 2011. The efforts to increase the production and productivity of wheat crop to feed large population of the country by conducting effective scientific trainings and demonstration of agriculture crops on farmer's field on a larger scale. Therefore, the present study was carried to find out the wheat yield gap between demonstrated plots 
and traditional farmers practices and motivate the farmers to adopt scientific technology for the production of wheat from sowing to harvest period.

\section{Materials and Methods}

60 Front Line Demonstration (FLD) has conducted during 2017-18 to 2018-19 in 24.0 ha area on farmer's field (FP) of different villages of Kurukshetra. In FLD high yielding variety of wheat (WH-1105) were shown in farmer's field by following all the instructions mentioned in Package of Practices (PP) of Rabi crops published by CCSHAU, Hisar. Soil of all the villages were clay loam with low in nitrogen and organic matter, medium to high in potassium and low in phosphorous level. In FLD conducted by KVK Kurukshetra at farmer's field, use of high yielding variety of wheat crop (WH1105), timely irrigations, sowing of seeds, application of weedicides, insecticides, control to termite by using Chloropyrifos in FLD fields as given in Package of Practices of Rabi crops. KVK Kurukshetra scientist has trained the farmers before conducting the FLD in farmer's field and time to time visited to the farmer's field for inspection. Site selection and layout of farmers field for demonstration were followed the guidelines as given by Choudhary, 1999. The output data were collected from FLD plots as well as traditional farmer's practices plots and finally the Technology gap, Extension gap and Technology index were analysed with the following formulas.

Technology gap $=$ potential yield - farmer's practices yield

Extension gap $=$ demonstration yield farmer's practices yield

Technology Index $=\frac{\text { Potentialyield }- \text { Demonstration yield }}{\text { Potential yield }} \times 100$

\section{Results and Discussion}

In Table: 1. 60 Front Line Demonstration were conducted from $2017-18$ to $2018-19$ in 24.0 ha area on farmer's field. In FLD all the cultivation practices of wheat crop were followed as mentioned in Package of Practices of Rabi crops like use of high yielding variety of wheat (WH-1105), timely sowing of crop, line sowing, pre and post emergence of weedicide, timely irrigations, use of fertilizers with proper doses, use of proper concentration and timely application of pesticides, use of Chloropyrifos in fields which were infested with termites etc. The average yield of wheat crops under FLD fields was $55.7 \mathrm{q} / \mathrm{ha}$ over FP i.e. $52.4 \mathrm{q} / \mathrm{ha}$. It was found that 6.2 and 5.6 percent more yield was recorded in demonstration field than farmer's practices during 2017-18 and 201819 respectively. More yield of wheat was recorded 54.6 q/ha during 2017-18 and 56.8 $\mathrm{q} /$ ha during 2018-19 in demonstration plots whereas, 51.2 and $53.6 \mathrm{q} /$ ha were recorded in traditional farmers practices field in 2017-18 and 2018-19 respectively. Mamta et.al., 2020 also reported that the wheat yield was higher in demonstrated plots than traditional farmers practices. Similar observation was also reported by Pagaria et.al., 2019 in moong grain yield. Average yield of wheat was recorded 55.7q/ha and $52.4 \mathrm{q} / \mathrm{ha}$ in demonstrated plots and farmer's practices respectively. Extension gap of wheat yield was recorded maximum in the year 2017-18 i.e., $3.4 \mathrm{q} / \mathrm{ha}$ whereas; minimum was recorded in second year i.e., 2018-19. The average extension gap of both the years was $3.30 \mathrm{q} / \mathrm{ha}$ between FLD plots and FP plots. Lower wheat crop yield in farmer's field may be due to the technology gap as mentioned in Package of Practices. Technology gap was recorded more in the year 2017-18 i.e. 8.8 $\mathrm{q} / \mathrm{ha}$ than 2018-19 i.e.6.4 q/ha. The technology index showed the feasibility of the improved technology at the farmer's field. 
The lower the value of technology index, feasibility of technology will increase. The gap in technology index during both the years may be due to the difference in the soils fertility status, adverse climatic conditions, and poor management of pesticides application. The yield gap of wheat crop between demonstration plots and farmers practices plots may be due to the farmers has not followed the improved Package and Practices from sowing to final harvest period but in case of demonstration plots the yield of wheat crop was more than traditional farmer's practices due to the application of proper and balance fertilizers doses like urea, DAP etc coupled with improved variety, timely pest control and timely irrigate the demonstrated plots reported by Mamta et. al., 2020 in wheat crops. Kumar et. al., 2020 reported that wheat yield under frontline demonstration with improved variety found higher than from local check which could further be increased by adopting recommended production technology.

Table.1 Comparison of wheat yield gap between FLD with farmers practices

\begin{tabular}{|c|c|c|c|c|c|c|c|c|c|c|c|c|}
\hline \multirow{2}{*}{$\begin{array}{l}\text { Sr. } \\
\text { No. }\end{array}$} & \multirow[t]{2}{*}{ Year } & \multirow[b]{2}{*}{ 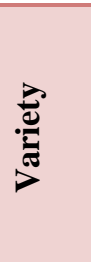 } & \multirow[b]{2}{*}{ 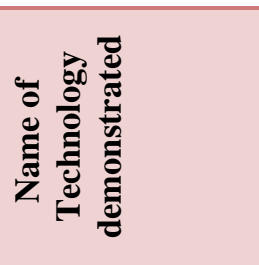 } & \multirow[b]{2}{*}{ 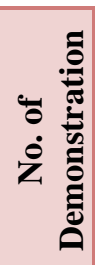 } & \multirow[b]{2}{*}{ 总 } & \multicolumn{3}{|c|}{ Yield (q/ha) } & \multirow[b]{2}{*}{ 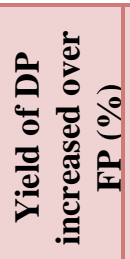 } & \multirow[b]{2}{*}{ 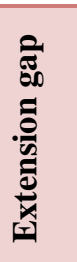 } & \multirow[b]{2}{*}{ 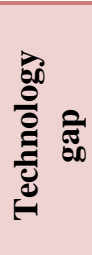 } & \multirow[b]{2}{*}{ 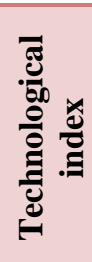 } \\
\hline & & & & & & PY & D.P & F.P & & & & \\
\hline 1 & $2017-18$ & \multirow[b]{2}{*}{$\stackrel{1}{3}_{3}^{1} \stackrel{n}{0}$} & \multirow{2}{*}{$\begin{array}{l}\text { As mentioned in } \\
\text { Package of } \\
\text { Practices of Rabi } \\
\text { crops }\end{array}$} & 40 & 16.0 & 60 & 54.6 & 51.2 & 6.2 & 3.4 & 8.8 & 9.0 \\
\hline 2 & 2018-19 & & & 20 & 8.0 & 60 & 56.8 & 53.6 & 5.6 & 3.2 & 6.4 & 12.6 \\
\hline \multicolumn{6}{|c|}{ Average } & 60 & 55.7 & 52.4 & 5.9 & 3.3 & 7.6 & 10.8 \\
\hline
\end{tabular}

PY $=$ Potential Yield, D.P. $=$ Demonstration Practices and F.P $=$ Farmer's Practices

Table.2 Economics gap of wheat crop between Demonstrations and Farmer's practices

\begin{tabular}{|c|c|c|c|c|c|c|c|c|c|}
\hline $\begin{array}{l}\text { Sr. } \\
\text { No. }\end{array}$ & Year & \multicolumn{4}{|c|}{$\begin{array}{c}\text { Economics of Demonstrations } \\
\text { (Rs/ha) }\end{array}$} & \multicolumn{4}{c|}{$\begin{array}{c}\text { Economics of Farmer's Practices } \\
\text { (Rs/ha) }\end{array}$} \\
\cline { 3 - 11 } & & $\begin{array}{c}\text { Gross } \\
\text { cost }\end{array}$ & $\begin{array}{c}\text { Gross } \\
\text { return }\end{array}$ & $\begin{array}{c}\text { Net } \\
\text { return }\end{array}$ & $\begin{array}{c}\text { B:C } \\
\text { ratio }\end{array}$ & $\begin{array}{c}\text { Gross } \\
\text { cost }\end{array}$ & $\begin{array}{c}\text { Gross } \\
\text { return }\end{array}$ & $\begin{array}{c}\text { Net } \\
\text { return }\end{array}$ & $\begin{array}{c}\text { B:C } \\
\text { ratio }\end{array}$ \\
\hline $\mathbf{1}$ & $2017-18$ & 59440 & 94730 & 35290 & $1: 59$ & 66410 & 88830 & 22420 & $1: 34$ \\
\hline $\mathbf{2}$ & $2018-19$ & $\mathbf{3 2 2 5 0}$ & 104512 & $\mathbf{7 2 2 6 2}$ & $\mathbf{3 : 2 4}$ & $\mathbf{3 4 4 0 0}$ & 98624 & $\mathbf{6 4 2 2 4}$ & $\mathbf{2 : 8 6}$ \\
\hline & Average & $\mathbf{4 5 8 4 5}$ & $\mathbf{9 9 6 2 1}$ & $\mathbf{5 3 7 7 6}$ & $\mathbf{2 : 4 2}$ & $\mathbf{5 0 4 0 5}$ & $\mathbf{9 3 7 2 7}$ & $\mathbf{4 3 3 2 2}$ & $\mathbf{2 : 1 0}$ \\
\hline
\end{tabular}

Table: 2. Showed that the Economic status of FLD and FP. This table clearly showed that the $\mathrm{B}: \mathrm{C}$ ratio was more in FLD plots as compared with farmer's practices plots during both the years of studied. The average net return of both the years in demonstrated plot was Rs 53776.0 whereas net return was lower in farmer's practices i.e., Rs 43322. The average cost benefit ratio was recorded 2:42 and 2:10 in FLD plots and farmer's practices respectively. This indicated that application all the technologies of wheat growing as mentioned in Package of Practices of Rabi crops was helpful for obtaining higher benefit than traditional farmer practices. Hence, favourable cost benefit ratios proved the economic viability of the interventions and convinced the farmers on the utility of 
interventions. Matharu and Tanwar (2018) also reported that the recommended technologies applied in summer mung gave higher mean net return per hectare with higher benefit cost ratio as compared to farmers practice. Similar results were also reported by Mamta et. al., 2020 in wheat crop.

It is concluded that front line demonstration programme conducted in farmer's fields is an effective tool for increasing the wheat yield production. In demonstration plots the yield of wheat crop was more as compared with farmer's practices due to proper and balance application of fertilizers doses coupled with improved variety (WH-1105) of wheat, proper application of pesticides, and timely irrigation in demonstrated plots. The yield gap can be overcome by providing the scientific knowledge to the farmers through training or motivate by the extension workers and scientists. Increases in the production of wheat resulted increases in the income of the farmers family.

\section{References}

Choudhary, B. N. (1999). Krishi Vigyan Kendra - A guide for KVK mangers. Publication, Division of Agricultural Extension, ICAR. pp: 73-78.

Kumar, A., Kumar,G., Singh, R., Kumar,A., Mandal. R.D and Hussain,J (2020). Impact of Front Line Demonstration on Yield and Economics of Wheat. Int.J.Curr.Microbiol.App.Sci. 10: 65-69.
Mamta, Singh F., Singh M.K, Bhatnagar P. and Devi, R (2020). Impact of front line demonstrations (FLD) on the yield of wheat (triticum aestivum L.) crop of kurukshetra district. International Journal of Agriculture Sciences. 12 (24): 10520-10521.

Matharu, K.S and Tanwar, P.S (2018). Impact of front line demonstration on production of summer moong in Barnala district. Agriculture Update. 13 (1): 62-66.

Munns, R and Tester., M. (2008). Mechanisms of salinity tolerance. Annual Review of Plant Biology59: 651681.

Pagaria,P., Choudhary,L.R., Dayal,H., Ram,G and Khan,T (2019). Role of front line demonstration on transfer of moong production technologies in Barmer district of Rajasthan. International Journal of Chemical Studies. 7(6): 1379-1381.

Ranawat, Y. H. R, Sisodiya, S.S and Punjabi, N.K. 2011. Adoption of improved maize cultivation practices by trained and untrained farmers of $\mathrm{KVK}$, Udaipur. Rajasthan Journal of Extension Education 19:144-147.

Shiferaw, B., Smale, M., Braun, H.J., Duveiller, E., Reynolds, $M$ and Muricho, G. (2013). Crops that feed the world. Past successes and future challenges to the role played by wheat in global food security. Food Security. 5: 291-317.

\section{How to cite this article:}

Fateh Singh, M. K.Singh, Praduman Bhatnagar and Mamta. 2021. Performance of Wheat Crop (WH-1105) Yield between Front Line Demonstrations and Farmers Practices. Int.J.Curr.Microbiol.App.Sci. 10(02): 188-191. doi: https://doi.org/10.20546/ijcmas.2021.1002.023 